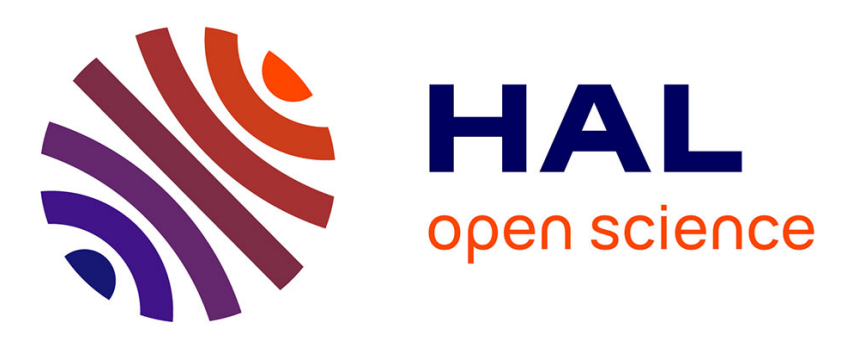

\title{
Recent fold growth and drainage development: The Janauri and Chandigarh anticlines in the Siwalik foothills, northwest India
}

\author{
Bernard Delcaillau, Jean-Michel Carozza, E. Laville
}

\section{To cite this version:}

Bernard Delcaillau, Jean-Michel Carozza, E. Laville. Recent fold growth and drainage development: The Janauri and Chandigarh anticlines in the Siwalik foothills, northwest India. Geomorphology, 2006, 76, pp.241-256. 10.1016/j.geomorph.2005.11.005 . halshs-01066745

\section{HAL Id: halshs-01066745 \\ https://shs.hal.science/halshs-01066745}

Submitted on 22 Sep 2014

HAL is a multi-disciplinary open access archive for the deposit and dissemination of scientific research documents, whether they are published or not. The documents may come from teaching and research institutions in France or abroad, or from public or private research centers.
L'archive ouverte pluridisciplinaire $\mathbf{H A L}$, est destinée au dépôt et à la diffusion de documents scientifiques de niveau recherche, publiés ou non, émanant des établissements d'enseignement et de recherche français ou étrangers, des laboratoires publics ou privés. 


\title{
Recent fold growth and drainage development: The Janauri and Chandigarh anticlines in the Siwalik foothills, northwest India
}

\author{
Bernard Delcaillau $^{\mathrm{a}, *}$, Jean-Michel Carozza ${ }^{\mathrm{b}}$, Edgard Laville ${ }^{\mathrm{a}}$ \\ a UMR-CNRS 6143 «Morphodynamique Continentale et Côtière » Universités de Caen, Esplanade de la Paix, BP 5186, \\ 14032 Caen Cédex, France \\ b Université L.Pasteur Faculté de Géographie 3, rue de l'Argonne F-67083 Strasbourg Cedex, France \\ Received 15 June 2005; received in revised form 20 July 2005; accepted 24 November 2005 \\ Available online 19 January 2006
}

\begin{abstract}
The active growth of a fault-and-thrust belt in frontal zones of Himalaya is a prominent topographical feature, extending 2500 $\mathrm{km}$ from Assam to Pakistan. In this paper, kinematical analysis of frontal anticlines and spatial mapping of active faults based on geomorphological features such as drainage pattern development, fault scarps and uplifted Quaternary alluvial fans are presented. We analyse the geomorphic and hydrographic expressions of the Chandigarh and the Janauri active anticlines in the NW India Siwaliks. To investigate the morphological scenario during the folding process, we used spatial imagery, geomorphometric parameters extracted from digital elevation models and fieldwork. Folding between the Beas and Sutlej Rivers gives clear geomorphological evidence of recent fold growth, presumably driven by movements of blind thrust faults. Structural style within the Janauri and Chandigarh anticlines is highly variable (fault-propagation folds, pop-up structures and transfer faults). The approach presented here involves analysis of topography and drainage incision of selected landforms to detect growth of active anticlines and transfer faults. Landforms that indicate active folding above a southwest-dipping frontal thrust and a northeastdipping back-thrust are described. Along-strike differences in ridge morphology are measured to describe the interaction of river channel patterns with folds and thrust faults and to define history of anticline growth. The evolution of the apparently continuous Janauri ridge has occurred by the coalescence of independent segments growing towards each other. By contrast, systematic drainage basin asymmetry shows that the Chandigarh anticline ridge has propagated laterally from NW to SE.
\end{abstract}

(C) 2005 Elsevier B.V. All rights reserved.

Keywords: Fold growth; Active tectonics; Drainage basins; Stream networks; Geomorphometry; Siwaliks; NW India

\section{Introduction}

Considerable progress has been made in recent years in defining frontal fault-propagation fold growth in regions of active tectonics. Topography and drainage patterns in regions of active deformation reveal aspects of faults and anticline growth (Tate et al., 2001; Medwedeff, 1992; Mueller and Talling, 1997; Delcaillau et

\footnotetext{
* Corresponding author.

E-mail address: bernard.delcaillau@unicaen.fr (B. Delcaillau).
}

al., 1998; Delcaillau, 2004; Burbank and Anderson, 2000; Husson and Mugnier, 2003; Sung and Chen, in press; Gupta and Ellis, 2004). The analysis of the relationships between active tectonics and surface processes/landforms reveals variations in the style of deformation and in the rate and direction of propagation of ridges. Nucleation, growth and lateral propagation of thrust faults interact with erosion to create the long-term drainage patterns (Elliott, 1976; Gupta, 1997; Champel et al., 2002). Drainage pattern has the potential to record evidence of the kinematics of folds and faults 
(Jackson et al., 1998). As landforms evolve due to the growth of frontal anticlines, drainage patterns adapt to modifications in surface slope (Keller and Pinter, 1996;
Jackson et al., 1998). Thus, frontal anticlines above active thrust faults display drainage anomalies and knickpoints on longitudinal profiles of stream channels.
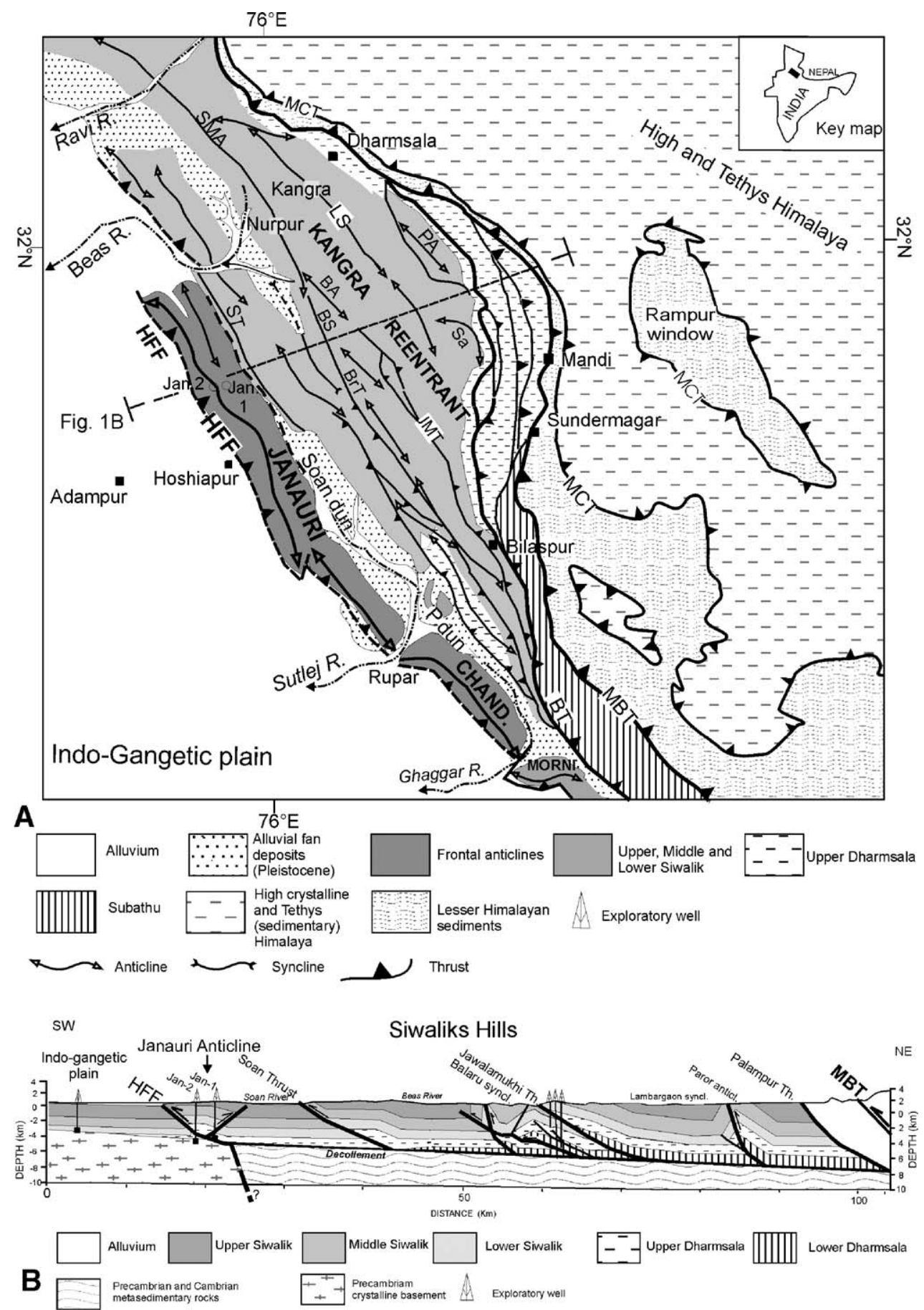

Fig. 1. Geological map of part of Siwalik (NW India) (adapted from Powers et al., 1998). (A) Geological map of part of the Sub-Himalaya. MCT: Main Central Thrust, MBT: Main Boundary Thrust, HFF: Himalayan Frontal Fault, ST: Soan Thrust, BT: Bilaspur Thrust, BS: Balaru syncline, BrT: Barsar Thrust, LS: Lambargaon syncline, Sa: Sarkaghat anticline, PA: Paror anticline, P dun: Pinjore dun, CHAND: Chandigarh anticline, Jan1 and Jan2: wells. (B) Structural cross section (location in A). 
In short, the fluvial drainage system is a highly sensitive indicator of active tectonics (Schumm, 1986).

In this study, we investigate the tectonic geomorphology of active folding over buried reverse faults in the NW India Siwaliks. The study focuses on the geomorphic and hydrographic expressions of the Chandigarh and the Janauri active anticlines (Fig. 1). We use along-strike differences in ridge morphology and drainage pattern to define the geometric evolution of these two frontal anticlines. Much of this analysis has been carried out using GIS (STRM, $90 \mathrm{~m}$ spatial resolution). The DEM data are used for extraction of topographic and drainage profiles, indicating changes in the topographic expression of Janauri and Chandigarh anticline ridges. These anticlines are wrinkle ridges, typically interpreted as fault-related folds formed above blind and emergent thrusts (Watters, 1988). In the foothills of frontal Himalaya, the growing anticlines and Himalayan Frontal Thrust (HFT) take up a significant part of the convergence (e.g. Delcaillau, 1992; Lavé and Avouac, 2000). Nevertheless, the PlioQuaternary evolution of the frontal Siwalik hills in NW India is poorly constrained, and the sense of movement in Quaternary times remains a matter of debate (Nakata, 1972; Nakata, 1989; Kumar et al., 2001; Valdiya, 2001). Geological evidence of active faulting is limited to the Himalayan Frontal Fault (Nakata, 1972; Valdiya, 2003; Thakur, 2004; Gupta and Ellis, 2004).

The aims of the study are to document the tectonic geomorphology of the anticline belt, the drainage systems and the structures that accommodate lateral propagation on folds.

\section{Geological setting (Fig. 1)}

The Himalaya range is the result of continental convergence between the Eurasian and Indian plates at rates varying from 44 to $61 \mathrm{~mm} /$ year (Minster and Jordan, 1978). The relief is a product of an imbricated thrust sheet (Schelling and Arita, 1991). Each mountain range correlates with a thrust sheet of the Main Central Thrust (MCT), the Main Boundary Thrust (MBT) and the Himalayan Frontal Thrust (HFT), which delineates the northern limit of the exposed Indian Plate. The active front of the Himalaya has migrated sequentially from the MCT to the MBT and then the HFT (Schelling and Arita, 1991; Delcaillau, 1992). The Siwalik-Ganges foreland basin constitutes a unique present-day active foreland system in a geodynamic context of intracontinental collision, where synorogenic sediments are incorporated into the outer part of the orogenic belt (Fig. 1A). The northern edge of the foreland basin is deformed and constitutes the Sub-Himalayan zone. It is formed by a succession of parallel and linear anticline ridges where their height varies from $600 \mathrm{~m}$ to $1500 \mathrm{~m}$. The Siwalik strata exhibit complex deformation (fault-propagation folds and thrusts). Across the Sub-Himalaya of NW India, a line-length balanced section shows a minimum shortening of $23 \mathrm{~km}$ (Powers et al., 1998). The width of the Siwalik area indicates a great variation due to the sinuosity of the Main Boundary Thrust. The Himalayan Frontal Thrust (HFT), separating the Siwalik hills and the Indo-Gangetic plain, is a southwest-vergent thrust fault. The HFT cuts Siwalik strata at the surface but is often a blind fault (Nakata, 1989). Several transverse lineaments detected in satellite imagery suggest segmentation of Himalayan frontal belt into different blocks (Banerjee, 2002). Rising anticline ridges of synorogenic Siwaliks deposits are separated from the main range front by longitudinal tectonic depressions called dun valleys.

The study area is located in the India Sub-Himalaya between the Beas River and the Ghaggar River. The Janauri and Chandigarh ridges constitute the Outer Siwalik Range. Beneath the Janauri anticline (Jan in Fig. 1B), the surface thrust faults merge downward into a decollement horizon of shales of the middle Cenozoic Dharmsala molass $\left(\sim 2.5^{\circ}\right.$, Powers et al., 1998; Yeats and Lillie, 1991). The basement offset controls the location of structures within the Siwalik hills and causes ramping of the decollement (Wiltschko and Eastman, 1983) (Fig. 1B). The GPS data show that the frontal thrust fault is locked with the advancing Indian plate along the decollement surface, at depths of 6-10 km (Banerjee and Bürgmann, 2002). In the frontal zone, along Ghaggar River and around Chandigarh, reverse faults with the length varying from 2 to 10 $\mathrm{km}$ have displaced Quaternary terrace levels (Malik et al., 2003). These active faults give a slip rate of about $1.6 \pm 0.1 \mathrm{~mm} /$ year.

\section{Methodology}

In this paper, we use the morphometrical indices like indicators of the morphological response to recent tectonic activity. As pointed out by Jackson and Leeder (1994), the shape and the structure of the drainage constitute a response to the uplift process, more or less modulated by lithological parameters. The reconstitution of the drainage pattern, combined with a description of the geometry of the tectonic structures, elucidate the evolution of a frontal anticline belt. 
Here, the morphometric data are not treated from a statistical point of view to determine an average state of the drainage system, but are spatialized in order to highlight the relative timing and the propagation of the anticline using a geographical information system. GIS is used to manage geodata such as digital elevation models (DEM) or remote sensing image and derived spatial information (drainage basin, drainage network and associated properties). DEM data used for this work result from Shuttle Radar Topographic Missions (SRTM). Details on acquisition methodology can be found in Farr and Kobrick (2000). The spatial horizontal resolution of the DEM is around $90 \mathrm{~m}$. The vertical average precision of SRTM DEM is about $7 \mathrm{~m}$ in this zone. Taking into account the size of the Janauri and Chandigarh anticlines (respectively $150 \mathrm{~km}$ and $50 \mathrm{~km}$ length) and that of basin drainage (average size around $20 \mathrm{~km}^{2}$ ), this resolution is sufficient for a good description of the anticline ridges and for a quantification of landforms. The DEM was used in association with remote sensed image (Ortho-rectified Landsat Enhanced Thematic Mapper) compressed Mosaics as displayed by NASA's Earth Science Enterprise Scientific Data Pur- chase Program. Delimitation of the morphological units was performed by threshold application on slope and azimutal maps derived from the DEM and confirmed by confrontation with hydrographic network and associated drainage basins automatically derived from the DEM. These data are used to consider the shape and organization of the drainage or to calculate various morphometric indices. Details of the indices used are show in Table 1.

The hydrographic networks were ordered according to the Horton's method (Horton, 1945). The longest segment of each elementary basin is then used to automatically extract the topographic longitudinal profiles from the rivers and to seek breaks in slope. Such knickpoints are potential indicators of the uplift of the anticline. The prominent drainage is then used to seek an indicator of the propagation of the deformation. Indeed, simulations by cellular automata have show that the development of the asymmetry of the drainage basins could be regarded as a good indicator of the differential uplift along a morphostructure and propagation of the deformation (Rebeiro-Hargrave, 1999; Salvany, 2004). In this study, we characterize the asymmetry of the drainage by using Cox's (1994) method. This one is

Table 1

Geomorphometric parameters of topography and drainage pattern

\begin{tabular}{|c|c|c|}
\hline Variables & Symbols & Acquisition methods \\
\hline \multicolumn{3}{|c|}{ Topographical variables of the anticline belt } \\
\hline Length & $\mathrm{Lb}$ & Data extracted from DEM \\
\hline Width & $\mathrm{lb}$ & Data extracted from DEM \\
\hline Amplitude & $\Delta \mathrm{H}$ & Data extracted from DEM \\
\hline Index of asymmetry of limbs & & Computed from DEM extracted data \\
\hline Mountain front sinuosity & Smf $=$ Lmf/Ls (Bull and McFadden, 1977) (1) & Computed from DEM extracted data \\
\hline Main slope of limb & $\mathrm{S}$ & Computed from DEM extracted data \\
\hline \multicolumn{3}{|l|}{ Variables of erosional landforms } \\
\hline \multicolumn{3}{|l|}{ Drainage basins } \\
\hline Nombre de bassin & & Data extracted from DEM \\
\hline Area & $\mathrm{Au}$ & Data extracted from DEM \\
\hline Basin relief & $\mathrm{H}$ & Data extracted from DEM \\
\hline Integral hypsometric & (Strahler, 1952) (2) & Computed from DEM extracted data \\
\hline Index of asymmetry & $\mathrm{AF}(\mathrm{Cox}, 1994)(3)$ & Computed from DEM extracted data \\
\hline Elongation ratio & $\operatorname{Re}(4)$ & Computed from DEM extracted data \\
\hline \multicolumn{3}{|l|}{ Drainage networks } \\
\hline $\begin{array}{l}\text { Physiography of drainage } \\
\text { pattern (parallel, treillis, radial, etc.) }\end{array}$ & & Data extracted from DEM \\
\hline Order & $\mathrm{Nu}$ & Data extracted from DEM \\
\hline Drainage density & $\mathrm{Du}(5)$ & Computed from DEM extracted data \\
\hline
\end{tabular}

(1) Smf: Lmf/Ls (Lmf: length of the mountain front along the mountain-plain junction; Ls: the straight-line length of the mountain front) (Bull and McFadden, 1977).

(2) The hypsometric curve is defined to divide the heights and areas by the total heights and total area, respectively. Hypsometric analysis has been performed to summarize the form and evolution of drainage basins.

(3) $\mathrm{AF}=100$. $(\mathrm{Ar} / \mathrm{At}), \mathrm{AF}$ is the index, $\mathrm{Ar}$ is the right hand side of the drainage basin, looking downstream, and At is the total area of the basin (Cox, 1994).

(4) $\mathrm{Re}=(2-A / p) / \mathrm{Lb}(A$ : area, Lb: length of the basin).

(5) Drainage density $\left(\mathrm{Du}=\sum \mathrm{Lu} / \mathrm{Au}\right.$, where $\sum \mathrm{Lu}$ is total stream length within basin of order $\left.\mathrm{u}\right)$. 
based on the computed index of asymmetry (AF), which can be calculated at each point of the hydrographic network. Asymmetry is defined as the position of the drainage within the basin and can be represented as a vector indicating direction of the folding. Repeated similar deviation can thus be interpreted as propagation. Moreover, we use the hypsometric integral (Strahler, 1952) like a complementary index to characterize the degree of dissection of the relief. The spatial organization of these values is also used like a proxy of the propagation of the uplift.

\section{Geomorphic response to active tectonics of the Janauri and Chandigarh frontal anticlines}

The Siwalik hills in NW India exhibit two anticlines: Jaunari and Chandigarh ridges (Figs. 1A and 2A). This belt of NW trending anticline ridges is about $150 \mathrm{~km}$ long and up 10-15 km wide, with summit elevations reaching $700 \mathrm{~m}$ above the Indo-Gangetic plain. These elongate ridges are interpreted as anticlines above a southwest-vergent subsurface thrust fault (Yeats and Lillie, 1991). In fact, this anticline belt is part of an active fault-related anticline system located on the hanging wall of the thrust fault along the southern front of the Siwalik hills. The geometry of the Januari anticline is constrained by deep bore hole data and the main structures are well known (Yeats and Lillie, 1991; Brozovic and Burbank, 2000). The anticlines are composed of Middle Siwaliks sandstones (Upper Miocene), Upper Siwaliks conglomerates (Pliocene to Lower Quaternary) and post-Siwaliks deposits (alluvial fan and terrace deposits). Near the Sutlej River, the thickness of the Upper Siwalik strata is about 2300 m (Karunakaran and Ranga Rao, 1976). The foothills are characterized by regional curvatures of the deformation front, which deviates from the general trend of thrust units of the Sub-Himalaya. The Janauri and Chandigarh fold belt is considered to be one of the most active structures of the Himalayan front. Forming a right-stepping echelon pattern, the NE-SW trending tear fault registered dextral displacement, while the less common $\mathrm{N}-\mathrm{S}$-oriented faults were characterized by sinistral movement (Fig. 2Bi). Several large earthquakes occurred along blind ruptures of the northwest Himalaya marked by the Saon and Pinjore duns, which themselves are controlled by main Siwalik frontal anticlines (Molnar and Pandey, 1989). The Pinjore Garden fault (PGF), striking NNW-SSE, cuts through the piggyback Pinjore Dun (Malik and Nakata, 2002) (Fig. 2Bi).

The Jaunari and Chandigarh anticlines, $150 \mathrm{~km}$ and $50 \mathrm{~km}$ long, respectively, run parallel to the Soan and
Pinjore duns from NW to SE (Fig. 2Bi). These duns include thick alluvial fans. In the Pinjaur dun, the fan sedimentation was initiated well before $57 \mathrm{ka}$ and continued up to $20 \mathrm{ka}$ BP (Suresh et al., 2002). The Quaternary alluvial fan deposits of Pinjaur Dun indicate erosion of the elongated relief caused by the Soan thrust activity (Fig. 1B).

\subsection{Geomorphic response to active tectonics of the segmented Janauri ridge}

Janauri ridge is long, linear to sinuous topographic highs. This anticline, located between the Saon and the Satluj Rivers, is interpreted as a fault-propagation fold which is kinematically linked to the HFT (Fig. 2A). In the NW fold belt, the geometry of the deep structure is constrained by two wells (Fig. 1B) (Powers et al., 1998). The symmetric and moderate amplitude folds are caused by the HFT fault that roots in the Lower Dharmsala Fm. The double vergent Janauri anticline, bounded by the HFT and a backthrust, is a pop-up structure (Fig. 1B). Mapping of emergent backthrust suggests a double wedge geometry.

Towards the southeast of the Janauri anticline, the crestal domain of the anticline is particularly narrow. It must be emphasized that this ridge presents an asymmetrical aspect (cross section F, Fig. 2Bii) This establishes that the southwest vergent anticline corresponds to faultpropagation fold. In the frontal zone, the thrust-fault scarp, reaching a height of $\sim 200 \mathrm{~m}$, is associated with the growth of the fold. The alluvial fan deposits seal the frontal thrust. The presence of straight southwest- and northeast-topographic scarps indicates emerged thrustfault segments. In some cases, the sinuosity of the interfluve line controls the Janauri crest asymmetry. The streams on the steep flanks have eroded headwards of the ridge crest in a number places (Fig. 2Bii). The southwestern limb of the anticline has steep slopes and small catchments.

Sections drawn through the Janauri fold indicate an abandoned alluvial fan across the anticline ridge (Fig. 2B). The ridge axis is horizontal in its central part but is inclined gently to the southwest and its northeast (Fig. $3 \mathrm{~B})$. The culmination of anticline is an elevated plateau rising up to $150-200 \mathrm{~m}$ over the actual fluvial deposits of the Indo-Gangetic plain. In the syncline of the segment 3 (Fig. 2Bi), a perched fan surface can be traced through the fold, implying $\sim 150 \mathrm{~m}$ of uplift has occurred across the fold since the frontal thrust and the backthrust. The converging of rivers $\alpha$ and $\beta$ in the Soan dun (Fig. 3B) could be controlled by the transfer fault F2 shifting the HFT (Fig. 2B). 


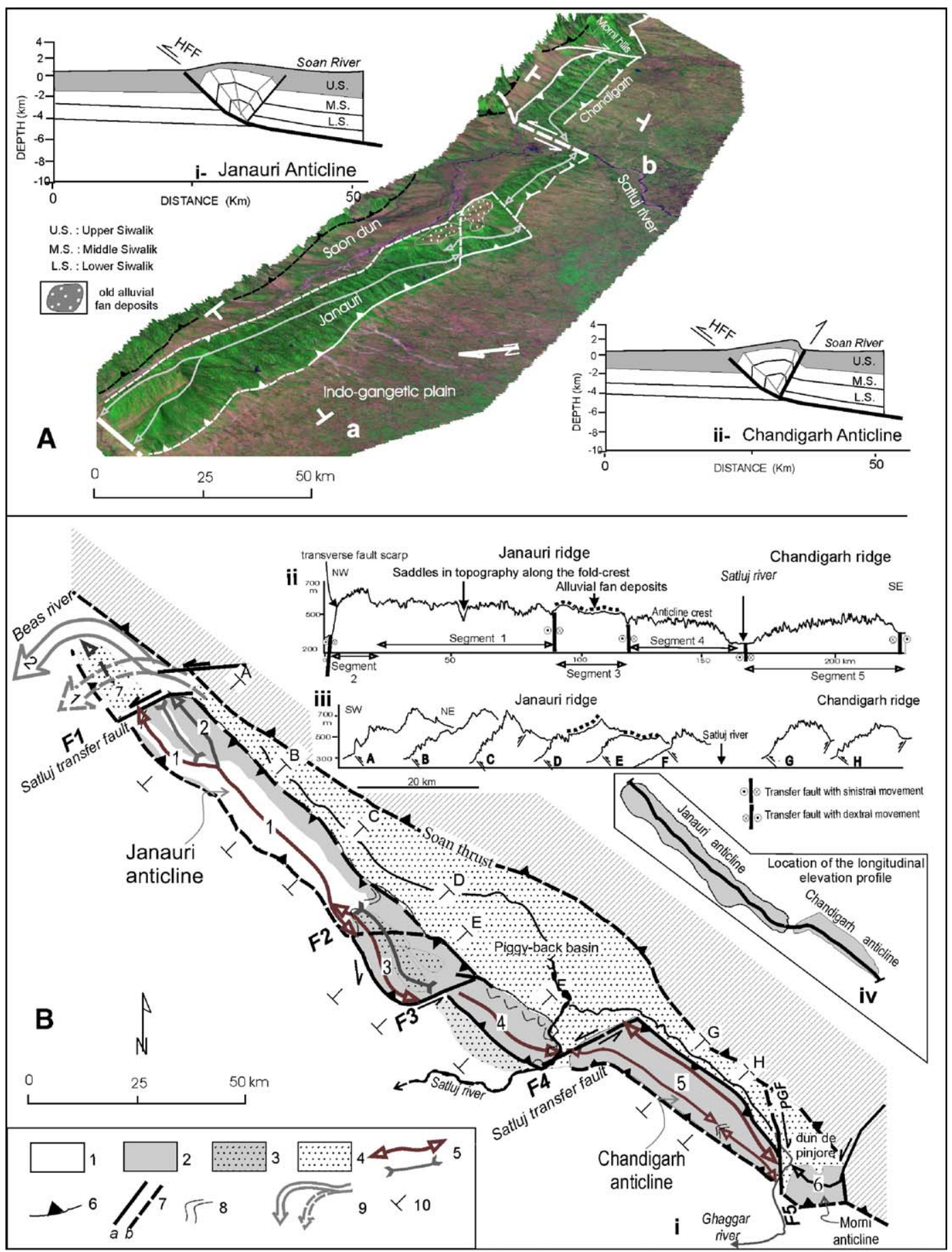

Fig. 2. Structures of the Janauri and Chandigarh anticlines. (A) DEM of the anticline ridges GIS (STRM, $90 \mathrm{~m}$ spatial resolution); (i and ii) structural interpretation of the Janauri and Chandigarh anticlines. (B) Structural pattern of the Satluj area; (i) structural map of the Janauri and Chandigarh ridges; (1) Middle Siwalik sandstones (Upper Miocene), (2) Upper Siwalik conglomerates (Pliocene and Lower Pleistocene), (3) uplifted and tilted Quaternary alluvial fan deposits, (4) actual alluvial deposits in piggy-back basins (duns), (5) modern alluvial fan deposits in the Indo-Gangetic plain, (6) anticline and syncline axis, (7) thrust, (8) fault (a: known, b: inferred), (9) bedding, (10) avulsion of the stream river, (11) location of the topographic cross-sections in Bii; PGF: Pinjore Garden fault. (ii) Longitudinal summit elevation profiles along the ridge crests; (iii) transversal topographic profiles; (iv) location of the longitudinal elevation profile in Bii. 

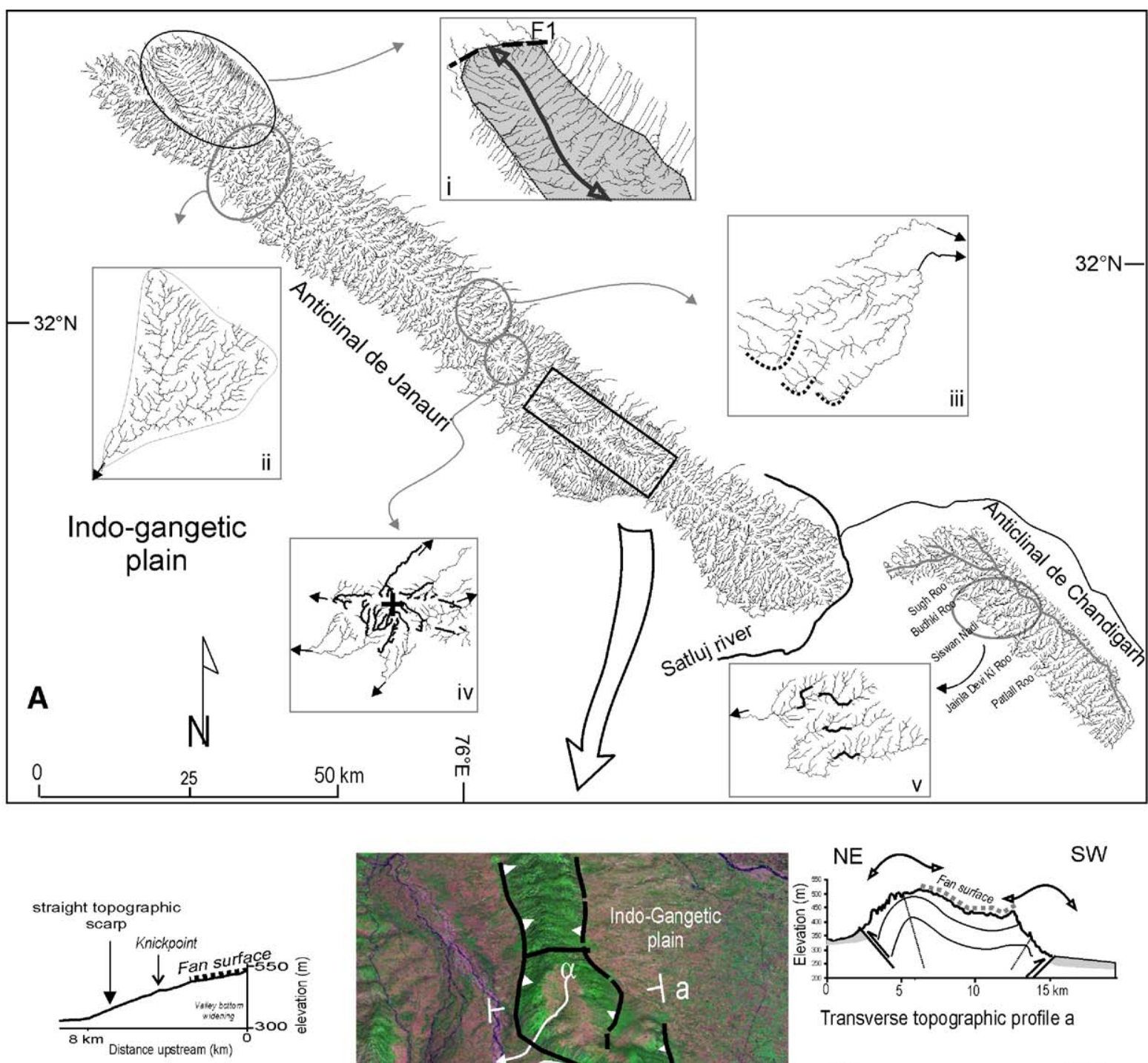

Longitudinal profile $\alpha$

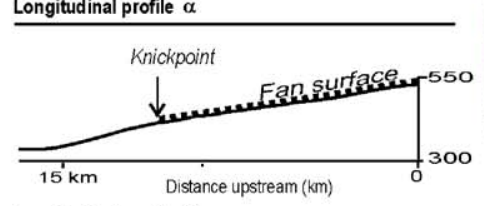

Longitudinal profile $\beta$

B
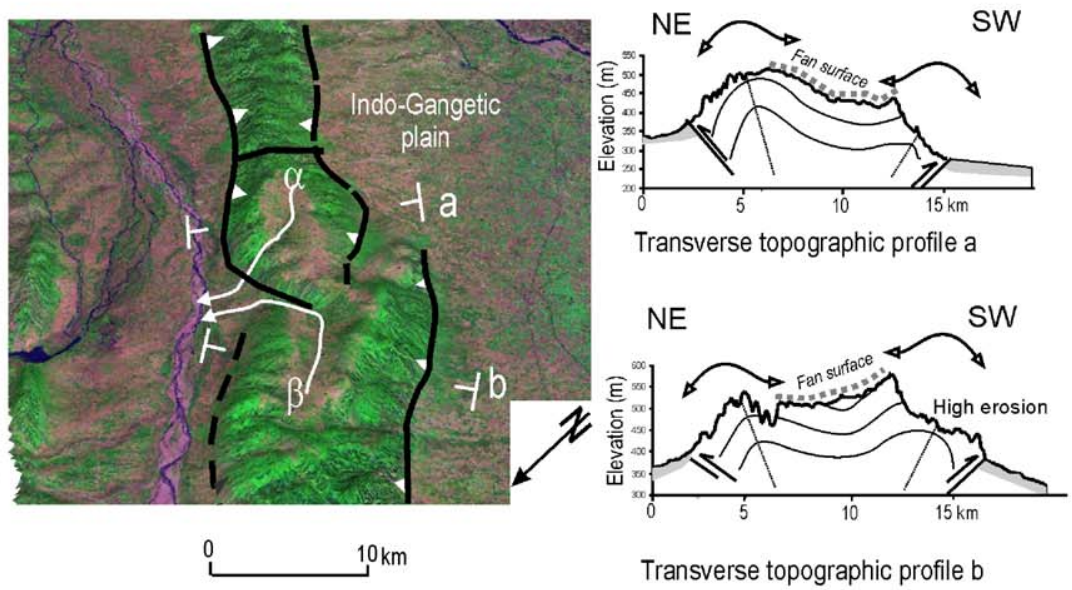

Transverse topographic profile b

Fig. 3. Drainage pattern of the Janauri anticline. (A) Drainage network; i, ii, iii, iv and $\mathrm{v}$ are different drainage networks; (B) diverted drainage pattern, simplified geological cross-sections and longitudinal profiles of two rivers ( $\alpha$ and $\beta$ ).

The segmented folds, apparently continuous, consist of several discrete transfer faults that are distinguished by small lateral offsets and by changes in strike. The Janauri ridge is bounded by NE-SW transverse faults (F1, F2, F3, F4 and F5, Fig. 2B). These transfer faults have a profound effect on the growth of the anticline ridge. The northwestern part of the segment 2 com- prises a transverse fault scarp forming the periclinal of the anticline. That scarp is characterised by a high amplitude relief ( $\sim 500 \mathrm{~m})$ (Fig. 2Biii), a long straight topographic scarp and facets spurs in its northeast part. It is striking that this transfer fault shifts the uplifted alluvium plain (segment 7, Fig. 2B). Strong morphological variability of the Janauri ridge indicates anti- 
cline segments (Fig. 2Bii). The fold segmentation is indicated in Middle and Upper Siwaliks bedding, from deflection and various altitudes of topographic axis, and anomalies of the drainage network (Fig. 4A). Four segments and their linkage are expressed in the active ridge crest morphology. Linearly, the elevation profile
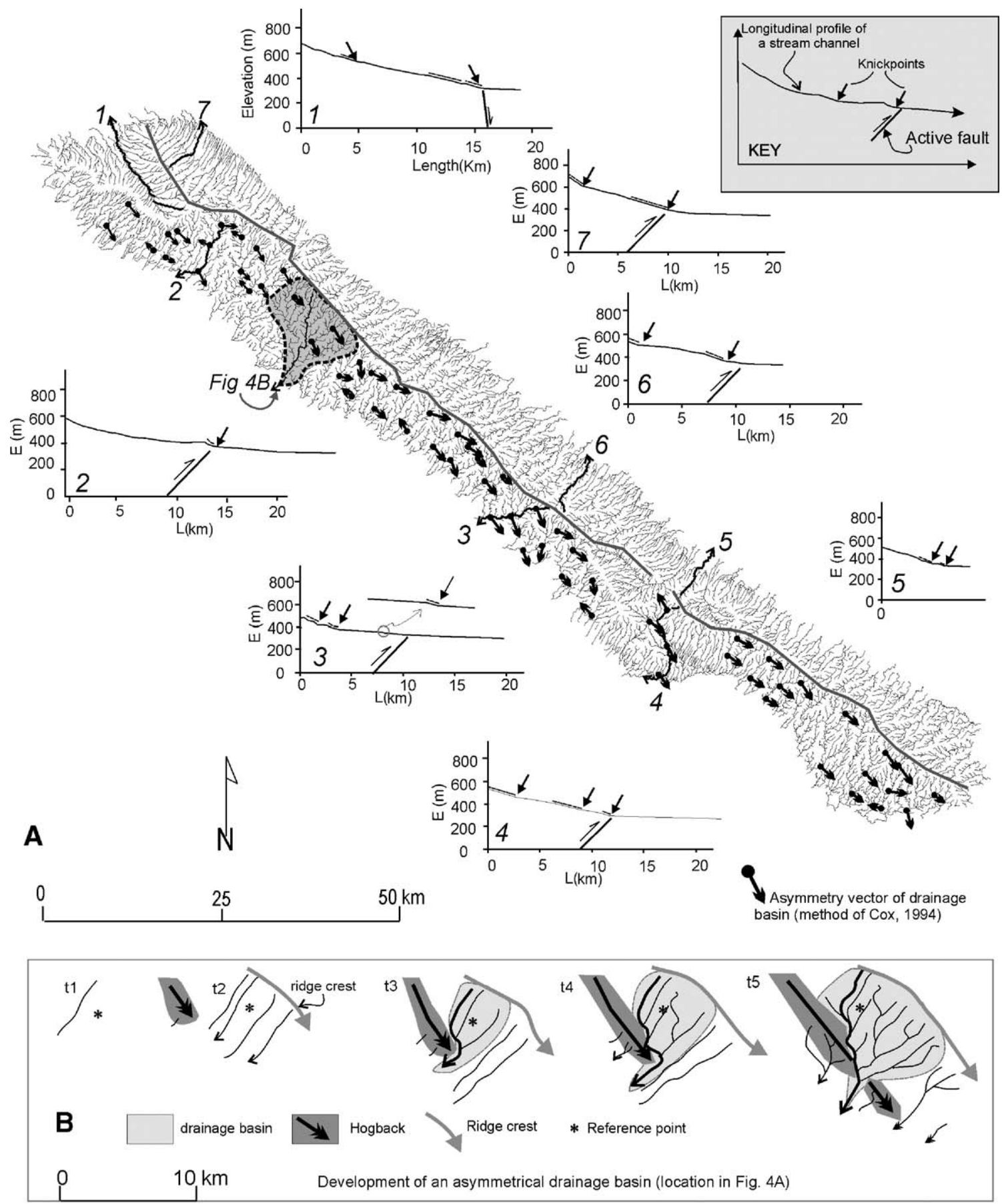

Fig. 4. Drainage map of Janauri anticline. (A) Drainage network and asymmetry of drainage basins with asymmetry vector of watersheds (method of Cox, 1994). The different numbers $(1,2,3,4,5$ and 6) denote longitudinal profiles of rivers. On long river profiles, arrows and discontinuous lines denote knickpoints, which indicate active tectonics. (B) Development of an asymmetrical drainage basin and lateral migration of the folding (localization in the map of A). 
is characterized by saddles (Fig. 2Bii). Segment boundaries coincide with overlapping thrust faults and in regions where fault tips have propagated towards one another.

\subsection{Geomorphic response to active tectonics of the asymmetrical Chandigarh ridge}

The NW trending Chandigarh ridge, located between the Satluj and Ghaggar Rivers, is about $50 \mathrm{~km}$ long and up 6-10 km wide, with summit elevations reaching $600 \mathrm{~m}$ above the Indo-Gangetic plain (Fig. 2). Its surface is about $302 \mathrm{~km}^{2}$. The geometry of the frontal thrust is not constrained by seismic data or deep borehole data. As opposed to the Janauri anticline, the Chandigarh ridge is more pronounced in its asymmetry. The width of the frontal flank is about 5 to 10 times larger than the backlimb. The main divide is located several kilometers behind the fold axis (Figs. 6a and 7a). Streams draining the frontal flank are deeply incised into Upper Siwalik conglomerates bedrock. The ridge presents a strongly dissected topography. The major rivers trend NE-SW cutting deep Vshaped valleys. Linear gullies with steep walls and landscape scars form a quasi-permanent extension of the strongly drainage network. In contrast, streams draining the northeast-facing backlimb are short (mean length $\sim 2 \mathrm{~km}$ ). These features suggest a marked disjunction between the positions of the fold axis and the drainage divide. From satellite imagery, the presence of a long and straight northeast-facing topographic scarp indicates a steeply dipping fault and a strong asymmetry of the ridge. The length of this sharp scarp is $50 \mathrm{~km}$ and its width varies between 1 and 4 $\mathrm{km}$. The amplitude of this relief is $\sim 100-300 \mathrm{~m}$ and its slope is $>45 \%$. From a morphological point of view, this scarp is mainly due to a backthrust fault. Homogeneous lithology, high drainage density, steepness of small streams and lower sinuosity of an abrupt scarp, approaching 1.0, are geomorphic features related to the uplift and the dissection of an highly tectonically active mountain front.

\section{Responses of the drainage basins to the Janauri and Chandigarh anticlines growth}

In the front of the propagating thrust, along-strike variations in the anticline have been inferred from hydrological and morphological markers. In this study, detailed investigation of the drainage pattern reveals their active migration into the limbs of the anticlines. We have used morphometric methods to evaluate direction of the growing anticlines. The drainage divide is perpendicular to the streams on both of its flanks. The southwestern and northeastern forelimbs are characterized by dendritic drainage pattern. Some secondary tributaries are elongated and are at right angles to primary tributaries. Streams draining the ridges are deeply incised into friable, poorly consolidated PlioQuaternary conglomerates and sandstones (Upper Siwalik Fm). We describe a local fluvial system specific to each fold segment.

\subsection{Streams response of the Janauri ridge anticline growth}

One of the most remarkable features of drainage networks in active fold-and-thrust belts is the occurrence of transverse rivers cutting the axial line of anticlines (Burbank and Anderson, 2000; Delcaillau, 2004). In the NW India, the Satluj River flows in a longitudinal course from NW to SE in the Soan dun (Fig. 1A). The Beas and Satluj Rivers are diverted around of the northwest and southeast ends of the Janauri anticline (Fig. 3A). Rivers incise through the limbs of the ridge anticline. The drainage network displays a parallel pattern normal to the Upper Siwalik conglomerate bedding. Streams on forward limbs have eroded headwards considerably to produce a sinuous divide.

The dense dendritic drainage network coincides with the steep flank to the Janauri fault-propagation anticline. In the southwestern limb, the streams are highly eroded headwards. The stream networks are developed on the two limbs of the Janauri anticline as marked asymmetric drainage basins in the right bank (forelimb) and the right bank (hinterland) of rivers. Many of the rivers and streams, which cross the thrust and backthrust scarps, show breaks in their longitudinal profiles. Knickpoints along channels cut the southwest and northeast scarp (Fig. 4A).

Neotectonic features are emphasized by asymmetry and drainage anomalies. First, the asymmetry of the anticline is more pronounced in the southeastern zone (cross-section F, Fig. 2Biii). The southwestern limb of the ridge is subjected to a strong fluvial erosion. The major rivers trend east-west cutting deep V-shaped valleys. Linear gullies with steep walls and landscape scars form a quasi-permanent extension of the drainage network. Secondly, stream courses are often guided or deflected by faults or hogbacks (Fig. 4B). The NE-SW trending transfer faults (F1, F2, F3 and F4) are consistent with an $\mathrm{N}-\mathrm{S}$ compression, which accommodated the strike-slip motion and created tectonically uplifted blocks (Fig. 2B). These blocks are characterized by the 
contorted drainage patterns. Drainage networks are disturbed by radial pattern which indicate recent uplift movement (Figs. 3Ad and 5A). Thirdly, the southeastward lateral propagation of folding is also suggested by an increase in relief (Fig. 2Bii) and exposure of deeper stratigraphic layers in the fold segment 1 of the geomorphic system (Fig. 2Bi).

\subsubsection{Active folding of the anticline segment 1: evi-} dence revealed by morphology and drainage pattern

In the backlimb of this anticline segment, the drainage streams are characterized by a diversion of the beheaded rivers to the NW and some rivers show deflection parallel to fold axis (Figs. $3 \mathrm{Ab}$ and $4 \mathrm{~A}$ ). In the forelimb, detailed investigations of the drainage networks reveal evidence of stream deflections with lateral migration of the hogback (Fig. 4B). Other clear geomorphological indications of recent anticline growth and propagation of the deformation from
NW to SE include the following. First, the length of watersheds and the Strahler method of stream ordering (Strahler, 1952) are used to analyse 40 drainage basins in the SW limb of the segments 1 and 3 (Fig. 5). From a morphometric point of view, the increase in length and ordering of drainage basins from NW to SE may indicate a lateral growth of the anticline. Secondly, the northwestern limb of the anticline is characterized by large catchments (Figs. 3Aii and 4B). The southwestern front shows a high sinuosity and undeformed Quaternary sediments in filling embayments. The largest drainage basins, located in the forelimb, have a dendritic pattern, locally perturbed by faults and monoclines. In these large-sized catchment areas, the landscape is marked by wide V-shaped valleys with concave slope profiles. Rivers and streams cut the thrust scarp and do not show breaks in their longitudinal profiles indicate slow activity. In the central part of this anticline segment, the dendritic drainage net-

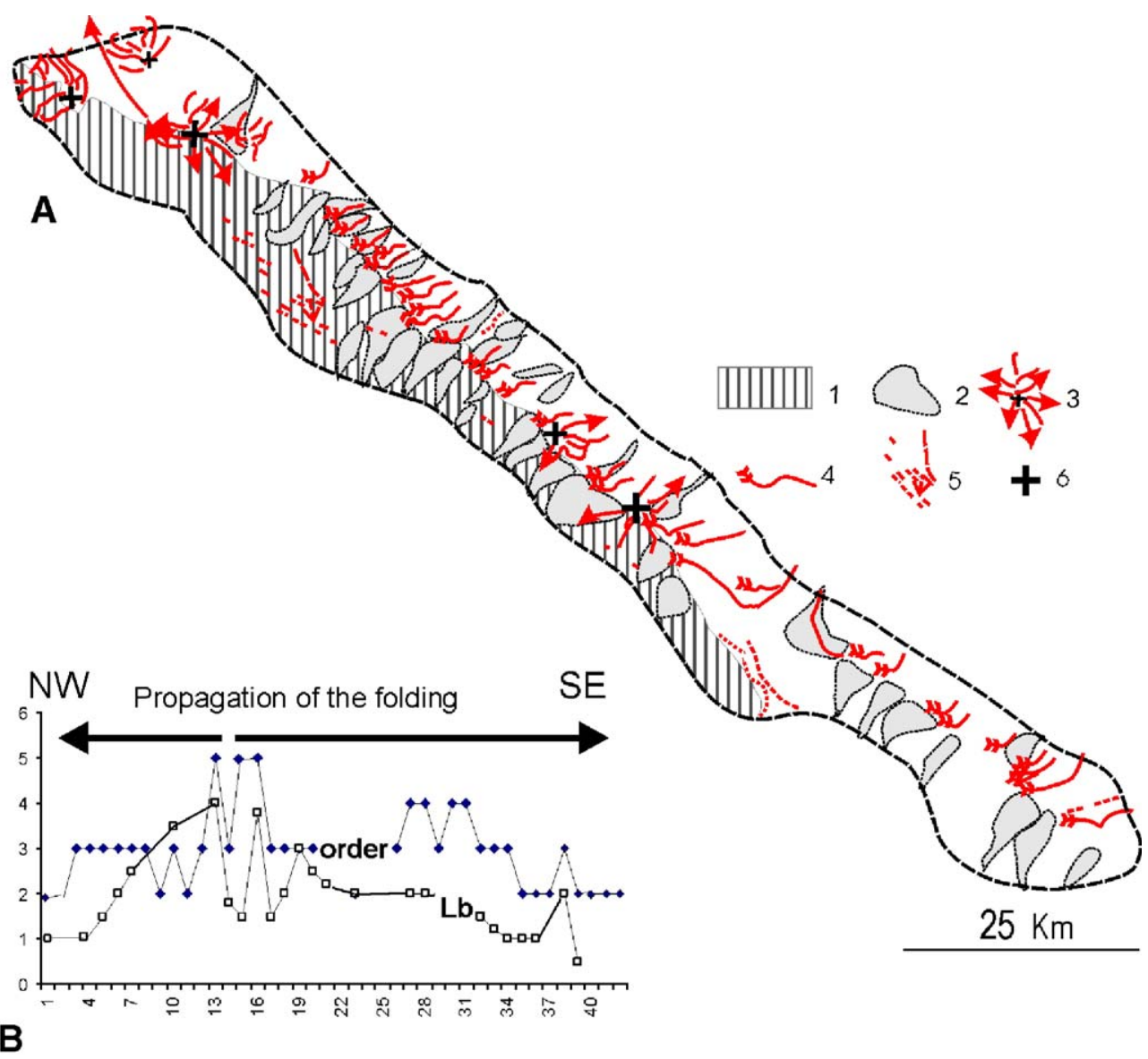

Fig. 5. Drainage pattern and anomalies of the river networks (Janauri anticline). (A) Deviation, anomalies and asymmetry of rivers; (1) southwestern limbs of the segments 1 and 3; (2) asymmetry of drainage basins [right bank (forelimb) and right bank (backlimb) of rivers]; (3) radial drainage network; (4) diversion of the beheaded stream rivers; (5) bedding; (6) recent uplift of culminations. (B) Relationship between Strahler's stream ordering and length of drainage basins $(\mathrm{Lb})$ in the southwestern limb of the segment 1 of the Janauri anticline. 
works indicate a long denudation period. Morphometric values of drainage basins (slope, length and area) decrease in direction towards the ends of this anticline, showing a double lateral migration of the uplift.

\subsubsection{Palaeodrainage and uplifted alluvial fan}

Remnants of several abandoned drainage channels and weathered fluviatile deposits are preserved on planar interfluves in the central part of the Janauri anticline
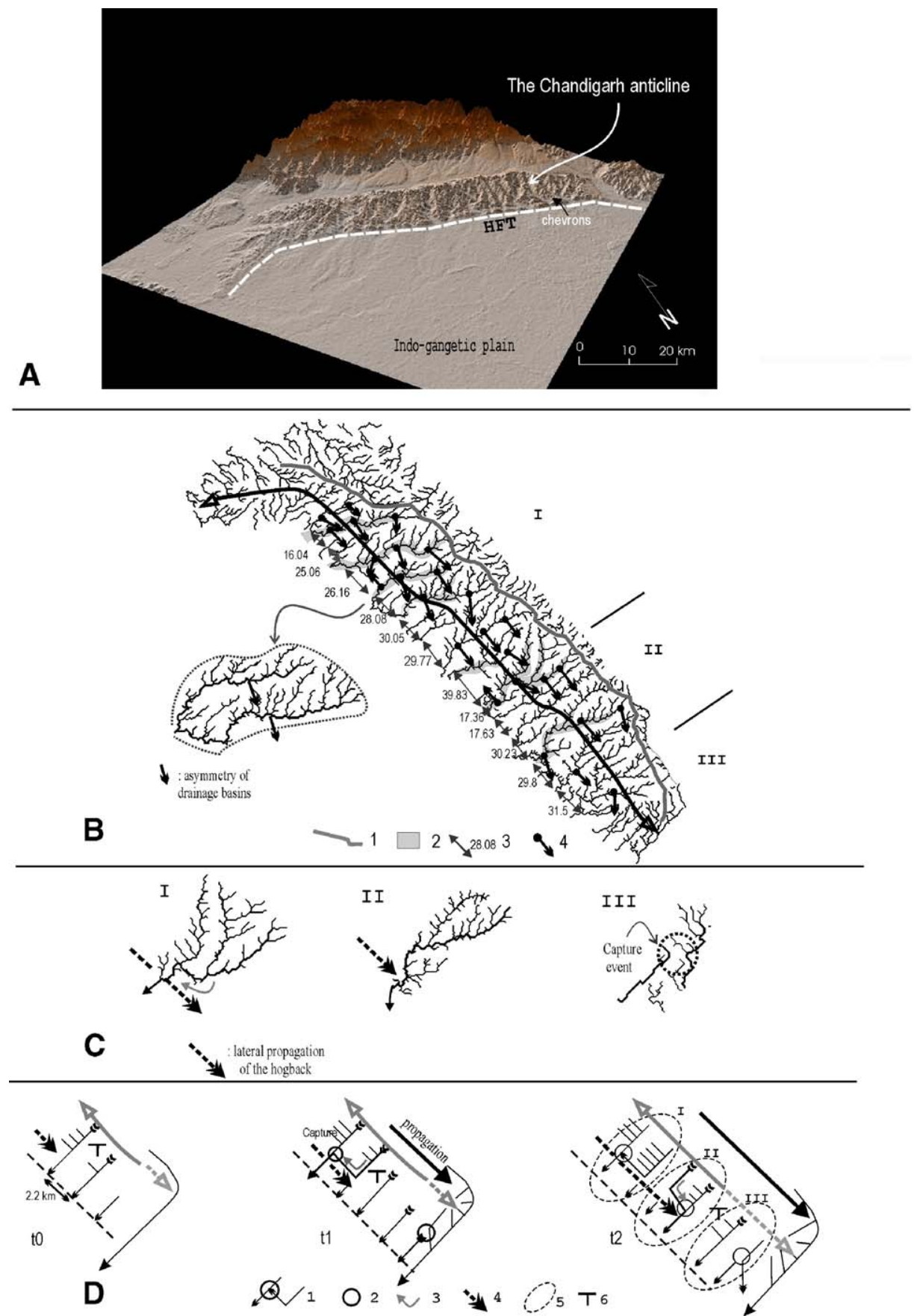

Fig. 6. Drainage map of Chandigarh anticline. (A) Digital elevation model of the Chandigarh ridge; (B) asymmetry of the drainage pattern: (1) ridge crest, (2) terrace deposits, (3) spacing of catchment outlets, (4) amount of asymmetry of drainage basins (method of Cox, 1994); I, II and III are delimited from drainage network particularities. (C) Different drainage networks (localization of zones in b): older (I), mature (II) and juvenile (III) drainage network. (D) Evolutionary scheme of asymmetric drainage basin; (1) capture of a stream channel, (2) capture event, (3) deflection, (4) migration of a hogback and lateral propagation of the folding, (5) sub-homogenous areas in the drainage network, (6) main slope. 
and on the internal back limb of frontal anticline (Fig. 3B). On axial culmination of the anticline, these old alluvial fan deposits indicate transverse palaeo-rivers that intersect the anticline ridge. Pleistocene beds have not been noticeably broken but are only gently folded. The presence of these high terrace deposits, developed on these clear planar interfluves rising up to $150 \mathrm{~m}$, suggests that the paleodrainage pattern was antecedent to the anticline formation. The preservation of hanging and dry valleys across the anticline suggests a continual forcing of drainage around the end of the growing fold segment. Uplift and lateral propagation of the folding can cause the stream to abandon its course leaving behind a water gap on the rising anticline ridge. Evidence of propagation of the folding from NW to SE has been demonstrated by the formation of water gaps and the diversion of the Saon River to the SE around Janauri anticline. Rates of deformation and lateral propagation of the ridge cannot be precisely determined, owing the lack of good radiometric dating in these weathered alluvial fan deposits.

\subsection{Drainage basins and streams response of the Chandigarh anticline growth}

A total of 33 drainage basins in the eastern limb and 19 drainage basins in the western limb of the Chandigarh anticline are analysed in present study. These watersheds have a moderate to marked elongate shape and are all oriented NE-SW (Fig. 6B). The backlimb is characterized by third and second order small catchments as opposed to the southwestern slope (fourth

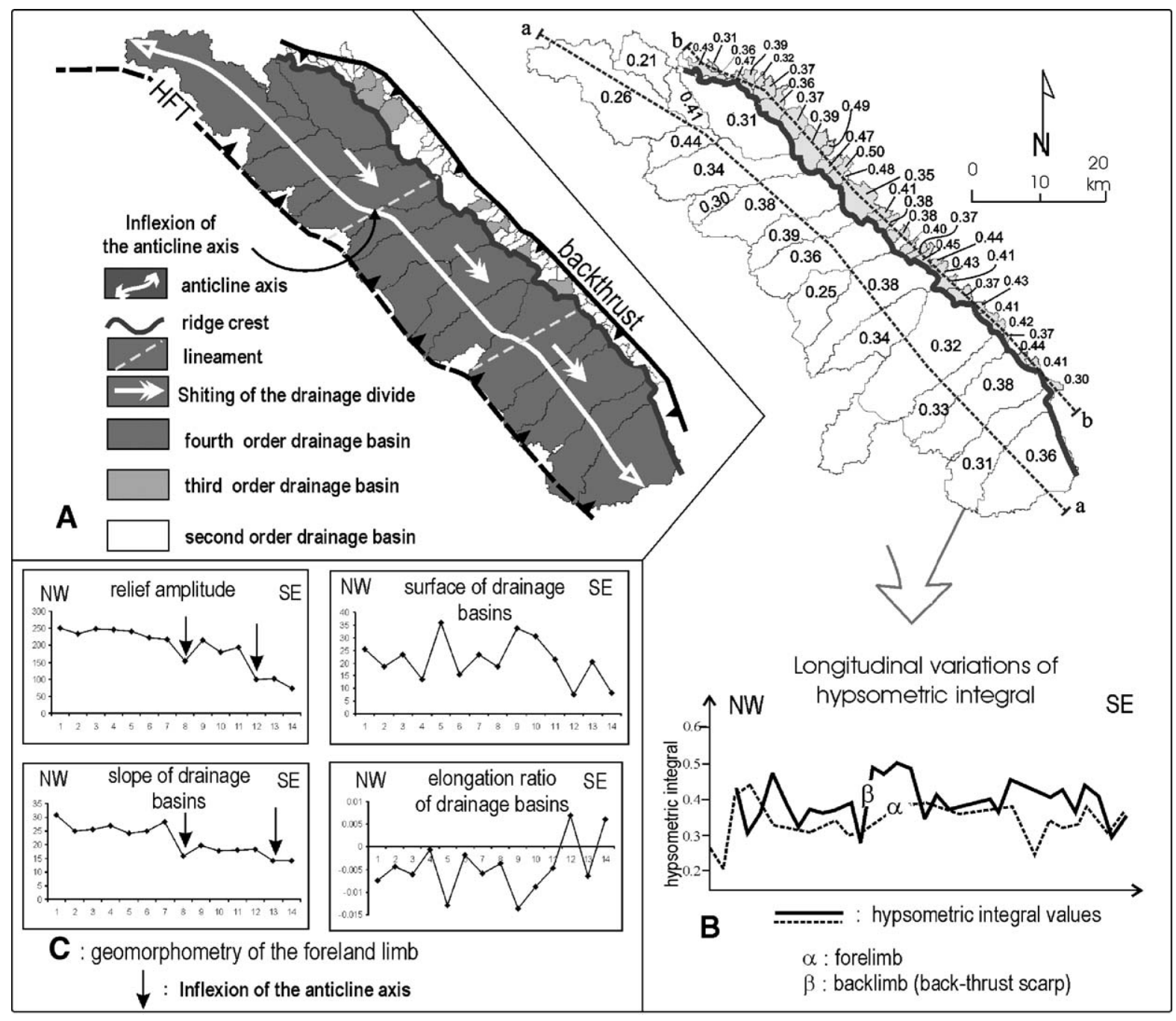

Fig. 7. Morphometry of drainage basins of Chandigarh anticline. (A) Map of Horton's stream ordering; (B) map of drainage basins and spatial variations of integral hypsometric values; (C) geomorphometric parameters of the anticline ridge (foreland limb). 
order) (Fig. 7A). The hypsometric analysis was performed to express quantitatively the evolution of the drainage basins (Fig. 7B). The hypsometric analyses, drawn for all of the basins in the study area, are ascribed to two main groups, each marked by a particular shape and range of hypsometric integral $(\delta)$. In the southwestern part, the first group is characterized by lower values of $\delta(\delta=0.33)$. In contrast, the $\delta$ varied in northwestern part between 0.39 to $0.50(\delta=0.4)$. The comparison between different hypsometric curves and integrals are related to the degree of drainage basins maturity and reflect relative age. Investigation on the divide morphology reveals generalized development of headwalls where frontal flank streams have cut the anticline axis. In the southwestern drainage basins, denudational processes on slopes are widespread and more active than downcutting. The landscape is marked by wide V-shaped valleys with concave slope profiles. From a geomorphological standpoint, the northern drainage basins have achieved a stationary equilibrium state (zone I, Fig. 6B and C). In the northeastern drainage basins, downcutting is strongly marked and the landscape is characterized by deep valleys. The steep drainage and high local relief are subjected to short-term uplift. This establishes that the foreland limb is more mature and less active than the backlimb, which is linked to an active backthrust.

The gentle foreland limbs are characterized by a system of parallel streams running perpendicular to the drainage divides and anticline axis. The longitudinal profiles of rivers display concave graded profiles. Significant changes of slope are rare. As opposed to Janauri ridge, the drainage divide is strongly shifted to the northeast (Fig. 6B). The divide is located several kilometres behind the fold axis and has retreated significantly into the backlimb of the active anticline.

The southwestern forelimb has a marked asymmetric drainage basin (Fig. 7A). This asymmetry is illustrated by the shape of the forelimb stream networks flowing from the hinge anticline to the Indo-Gangetic plain (Fig. 6B). This asymmetry is illustrated by the shape of the stream networks with the major tributaries coming from their right margin. In each drainage basin, the asymmetry occurs because the small tributaries perpendicular to the main streams erode more vigorously on the northwestern side of valley than on the southeast. Asymmetry factors (AF) generally show a uniform trend and have a similar direction and high values $(\mathrm{AF}=70-80)$. River channels are affected by lateral tilting by progressively migrating downtilt (Fig. 6D). Progressive tilting of the ridge and the consequent channel shift down-dip cause asymmetry of the stream network. This implies that rivers have migrated uniformly and largely to the southeast. The stream system must have started from northwest to the southeast, as is still seen today (zone III, Fig. 6B). We attribute these anomalies of the stream system to a propagation of the folding anticline to the southeast.

Relief amplitude and slope of the foreland limb indicate segmentation length. Several bent (sigmoidal) anticlines are linked to two lineaments oriented NESW (Fig. 7A). This anticline is post-dates inherited structure of the basements and could be controlled by blind deep transverse faults (Valdiya, 2001).

\section{Discussion: morphotectonical evolution of the Quaternary frontal anticlines}

Results of investigations into topographic variations and drainage network indicate growing and lateral propagation directions of the Jaunari and Chandigarh frontal anticlines during the Quaternary. The frontal thrust verges to the foreland and backthrusts to the hinterland (Soan and Pinjore duns). In this area, geomorphic parameters showing the growth of frontal anticlines have been observed: (1) asymmetry of the drainage indicating the direction of propagation of the segment anticline; (2) radial drainage basins showing push-ups - these culminations are en echelon arranged of overlapping anticlines or restraining bends; (3) alluvial fan deposits in the hinge anticline indicating capture of palaeothalwegs - these early streams channels, perpendicular to the anticline axis and crossing ridges in antecedent valleys, predate the ridge growth; (4) transverse profiles in the Janauri area suggest that ridges have been segmented by lateral propagation and, then, linked by individual fold-segments (Fig. 8).

By using these above geomorphic parameters, we demonstrate that morphological data and drainage networks in an active frontal zone can reveal fold growth. It is affected by a high spatial variability of folding and a sensitivity of the fluvial system to active tectonic processes, which are outlined by anomalies of streams channels and high asymmetry in drainage basins. Geomorphometry suggests drainage basins developed in response to uplift and lateral migration of folding. The Janauri ridge develops from the coalescing of independent segments that grew towards each other. Geomorphic evidence suggests that elementary ridges tend to link together creating a larger ridge anticline (Delcaillau, 2001; Tate et al., 2001; Davis et al., in press). The rising of the Janauri anticline indicates a divergent lateral propagation. In contrast, the drainage basin asymmetry of the Chandigarh anticline ridge is 


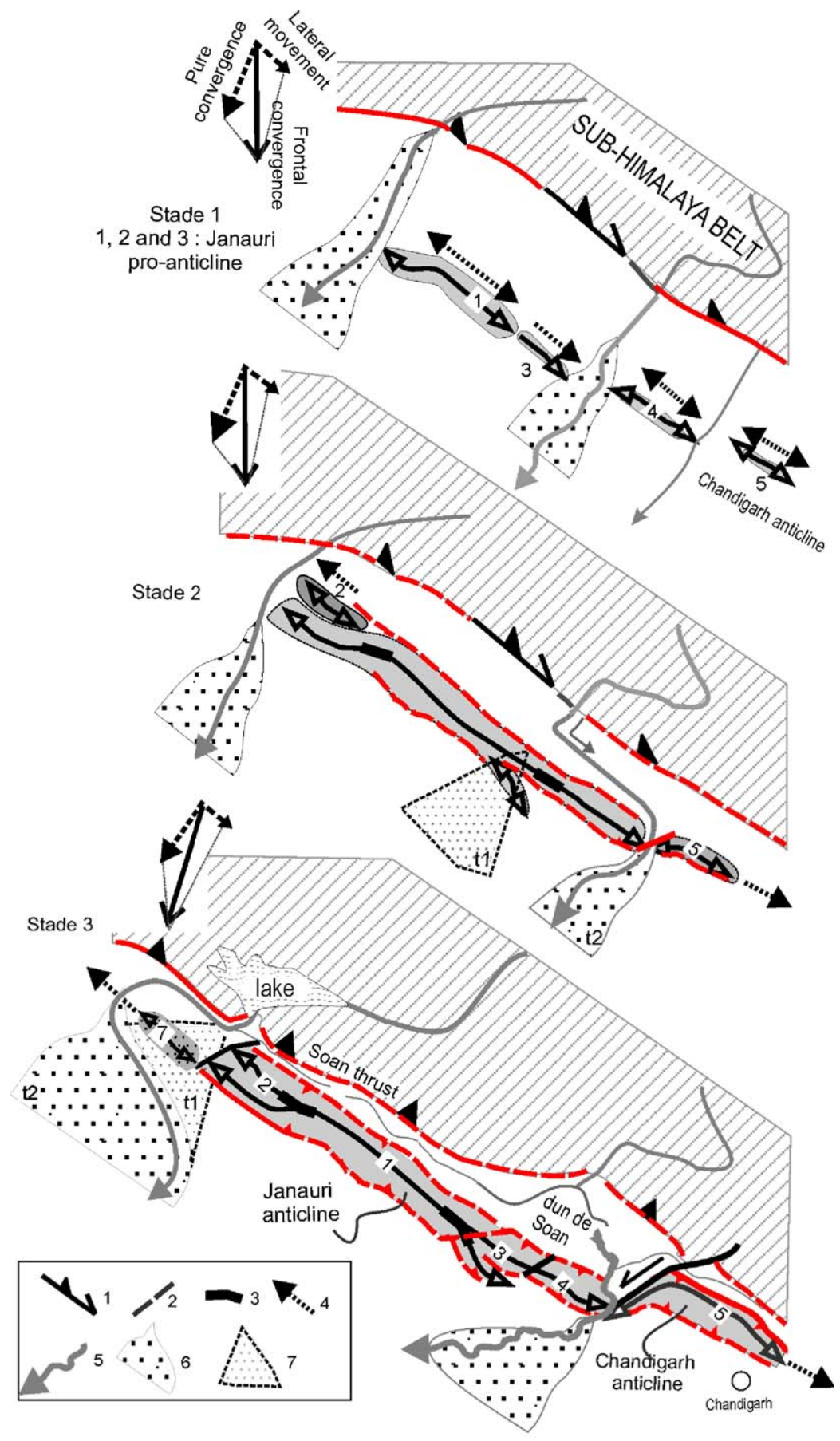

Fig. 8. Kinematics of the Janauri-Chandigarh anticlines: (1) thrusting and lateral deformation movement, (2) blind fault, (3) connection of segments, (4) lateral propagation direction of the deformation, (5) river, (6) active fan body, (7) inactive fan body. Numbers 1, 2, 3, etc. indicate different segments of ridge anticline.

systematic and propagates laterally from NW to SE (Fig. 7). The geomorphic expression of long-term folding indicates that the ridges and HFT have propagated laterally (Fig. 8).
In this study, strong variations in the style of deformation from the NW to SE are noted. Considering geomorphic parameters, such as topography and drainage patterns, the ridge belt has been subdivided 
into seven-fold segments (Fig. 2B). Morphotectonic analysis indicates a contrast between the two ridges: the Janauri anticline developed by the connection of four fold segments, while the Chandigarh anticline grew southeastward. Between active anticlines, the fault-related folding is mainly accommodated by the transfer faults of Beas (F1), Staluj (F4) and Ghaggar (F5) (Fig. 2) that absorb differential shortening of fault-propagation folds. Inside anticlines, transverse faults correspond to structural discontinuities that transform motion between segments and accommodate differential displacement within the folded Siwalik series. The basement architecture may have controlled the geometry of ramps in the footwall of the HFT. These faults are expressed by deformed alluvial fan surfaces. From the structural pattern, a kinematic model is proposed with two stages of development: (i) a first stage of fault-propagation fold growth associated with transfer faults (Fig. 8, stages 1 and 2)here, the NW-SE trending anticlines have recorded a right step over pattern in the dextral oblique-thrust zone; (ii) a second stage with a present pure shear deformation proved by using GPS data in the Himalayan Frontal Thrust zone (Banerjee and Bürgmann, 2002) (Fig. 8, stage 3).

\section{References}

Banerjee, P., 2002. Crustal shortening and tectonics of the NW Himalaya from GPS measurements. http://www.gisdevelopment. net/proceedings/asiangps/2002/overview/cds002pf.htm.

Banerjee, P., Bürgmann, R., 2002. Convergence across the Northwest Himalaya from GPS measurement. Geophysical Research Letters 29, 13, doi:10.1029/2002GL015184.

Brozovic, N., Burbank, D.W., 2000. Dynamic fluvial systems and gravel propagation in the Himalayan foreland. GSA Bulletin 112 (3), 194-412.

Bull, W.B., McFadden, 1977. Tectonic geomorphology north and south of the Garlock Fault, California. Geomorphology 1, 15-32.

Burbank, D.W., Anderson, R.S., 2000. Tectonic Geomorphology. Blackwell Scientific, Oxford. 270 pp.

Champel, B., Van der Beek, P., Mugnier, J.L., Leturmy, P., 2002. Growth and lateral propagation of fault-related folds in the Siwaliks of western Nepal: rates, mechanisms, and geomorphic signature. Journal of Geophysical Research 107 (B6), doi:10.1029/ 2001JB000578.

Cox, R.T., 1994. Analysis of drainage basin symmetry as a rapid technique to identify areas of possible Quaternary tilt-block tectonics: an example from the Mississippi embayment. Geological Society of America Bulletin 106, 571-581.

Davis, K., Burbank, D.W., Fisher D., Wallace, S., Nobes, D., in press. Thrust-fault growth and segment linkage in the active Ostler fault zone, New Zealand. Journal of Structural Geology.

Delcaillau, B., 1992. Les Siwaliks du Népal oriental. Presses du CNRS. 205 pp.
Delcaillau, B., 2001. Geomorphic response to growing fault-related folds: example from the foothills of central Taiwan. Geodinamica Acta 14, 265-287.

Delcaillau, B., 2004. In: Vuibert (Ed.), Reliefs et Tectonique récente. $262 \mathrm{pp}$.

Delcaillau, B., Deffontaines, B., Angelier, J., Déramond, J., Floissac, L., Souquet, P., Chu, H.T., 1998. Morphotectonic evidence from lateral propagation of an active frontal fold; the Pakuashan anticline, foothills of Taiwan. Geomorphology 24, 263-290.

Elliott, G., 1976. The energy balance and deformation mechanisms of thrust sheets. Philosophical Transactions of the Royal Society of London 238, 289-312.

Farr, T.G., Kobrick, M., 2000. Shuttle Radar Topography Mission produces a wealth of data. Amer. Geophys. Union Eos, vol. 81, pp. $583-585$.

Gupta, S., 1997. Himalayan drainage patterns and the origin of fluvial megafans in the Ganges foreland basin. Geology 25, 11-14.

Gupta, S., Ellis, M., 2004. Does the topography of actively growing folds mimic fold structures? The case of the Mohand anticline, frontal Himalaya. Geophysical Research Abstracts 6, 06593.

Horton, R.E., 1945. Erosional development of streams and their drainage-basin: hydrophysical and approach to quantitative morphology. Bulletin of the Geological Society of America 56, $275-370$.

Husson, L., Mugnier, J.L., 2003. Three-dimensional horizon reconstruction from outcrop structural data, restoration, and strain field of the Baisahi anticline, western Nepal. Journal of Structural Geology 25 (1), 79-90.

Jackson, J., Leeder, M., 1994. Drainage development of normal faults: an example from Pleasant Valley, Nevada. Journal of Structural Geology 16 (8), 1041-1059.

Jackson, J., Van Dissen, R., Berryman, K., 1998. Tilting of active folds and faults in the Manawatu region, New Zealand: evidence from surface drainage patterns, New Zealand. Journal of Geology and Geophysics 41, 377-385.

Karunakaran, C., Ranga Rao, A., 1976. Status of exploration for hydrocarbons in the Himalayan region - contributions to stratigraphy and structure: New Delhi. Himalayan Geology, Seminar, $1-72$.

Keller, E.A., Pinter, N., 1996. Active Tectonics. Prentice Hall Inc., Englewood Cliffs, New Jersey. 338 pp.

Kumar, S., Wesnousky, S., Rockwell, T.K., Ragnon, D., Thakur, V.C., Seitz, G.G., 2001. Earthquake recurrence and rupture dynamics of Himalayan Frontal Thrust, India. Science 294, $2328-2331$.

Lavé, J., Avouac, J.P., 2000. Active folding of fluvial terraces across the Siwaliks Hills, Himalaya of central Nepal. Journal of Geophysical Research 105, 5735-5770.

Malik, J.N., Nakata, T., 2002. Active fault and Late Quaternary deformation around Chandigarh and Pinjore Dun, NW Himalaya, India. Abstract in Conference on Quaternary Climate, Tectonics and Environment of Himalaya: Comparison with Other Regions, Nainital India.

Malik, J.N., Nakata, T., Philip, H., Virdi, N.S., 2003. Preliminary observations from a trench near Chandigarh, NW Himalaya and their bearing on active faulting. Current Science 85 (12), $1793-1798$.

Medwedeff, D.A., 1992. In: Mitra, S., Fisher, G.W. (Eds.), Geometry and Kinematics of an Active, Laterally Propagating Wedge Thrust, Wheeler Ridge, California, Structural Geology of Fold and Thrust Belts, John Hopkins Studies in Earth and Space Sciences, vol. 5, pp. 1-28. 
Minster, J.B., Jordan, T.H., 1978. Present day plate motions. Geophysical Research Letters 83, 5331-5354.

Molnar, P., Pandey, M.R., 1989. Rupture zones of great earthquakes in the Himalayan region. Proceedings of the Indian Academy of Sciences. Earth and Planetary Sciences 98, 61-70.

Mueller, K., Talling, P., 1997. Geomorphic evidence for tears faults accommodating lateral propagation of an active fault-bend fold, Wheeler Ridge, California. Journal of Structural Geology 19 (3-4), 397-411.

Nakata, T., 1972. Geomorphic History and Crustal Movement of Foothills of the Himalaya. Institute of Geography, Tohuku University, Sendai, p. 77.

Nakata, T., 1989. Active faults of the Himalaya of India and Nepal. In: Malinconico, L.L., Lillie, R.L. (Eds.), Tectonics of the Western Himalayas, Geological Society of America Paper, vol. 232, pp. 243-264.

Powers, P.M., Lillie, R.J., Yeats, R.S., 1998. Structure and shortening of the Kangra and Dehra Dun reentrants, Sub-Himalaya, India. GSA Bulletin 110 (8), 1010-1027.

Rebeiro-Hargrave, A., 1999. Large scale modelling of drainage evolution in tectonically active asymmetric intramontane basins using cellular automata. Zeitschrift für Geomorphologie. N.F., Supplementband 118, 121-134.

Salvany, J., 2004. Tilting neotectonics of the Guiadiamar drainage basin, SW Spain. Earth Surface Processes and Landforms 29, $145-160$.

Schelling, D., Arita, K., 1991. Thrust tectonics, crustal shortening, and the structure of the far-eastern Nepal Himalaya. Tectonics 10 (5), 851-862.

Schumm, S.A., 1986. Alluvial river response to active tectonics. In: Studies in National Research Council (Ed.), Active Tectonics. National Academy Press, Studies in Geophysics, Washington, D.C, pp. $80-94$.
Strahler, A.N., 1952. Hypsometric (area-altitude) analysis of erosional topography. Bulletin of the Geological Society of America 63, $1117-1142$.

Sung, O., Chen, Y.C., in press. Geomorphic evidence and kinematic model for quaternary transfer faulting of the Pakuashan anticline, central Taiwan. Journal of Asian Earth Sciences.

Suresh, N., Bagati, T.N., Thakur, V.C., Humar, R., Sangode, S.J., 2002. Optically stimulated dating of alluvial fan deposits of Pinjaur Dun, NW Sub Himalaya. Current Science 82 (10), 1267-1274

Tate, A., Mueller, K.J., Golombek, 2001. Geometry and kinematics of wrinkle ridges on lunae and solis plana, Mars: implications for fault/fold growth history. Lunar and Planetary Science XXXIII.

Thakur, V.C., 2004. Active tectonics of Himalayan Frontal Thrust and seismic hazard to Ganga plain. Current Science 86 (11), $1554-1560$.

Valdiya, K.S., 2001. Reactivation of terrane-defining boundary thrusts in central sector of the Himalaya: implications. Current Science 81 (11), 1418-1431.

Valdiya, K.S., 2003. Reactivation of Himalayan Frontal Fault: implications. Current Science 85 (7), 1031-1040.

Watters, T.R., 1988. Wrinkle ridge assemblages on the terrestrial planets. Journal of Geophysical Research 93, 10236-10254.

Wiltschko, D.V., Eastman, D., 1983. Role of basement warps and faults in localizing thrust fault ramps. In: Hatcher, R.D., Williams, H., Zeitz, I. (Eds.), Contributions to the Tectonics and Geophysics of Mountain Chains, Geological Society of America Memoir, vol. 158 , pp. $177-190$.

Yeats, R.S., Lillie, R.J., 1991. Contemporary tectonics of the Himalayan Frontal Fault system: folds, blind thrusts and the 1905 Kangra earthquake. Journal of Structural Geology 13 (2), $215-225$. 